\title{
Origanum majorana Leaf Extract
}

National Cancer Institute

\section{Source}

National Cancer Institute. Origanum majorana Leaf Extract. NCI Thesaurus. Code C107339.

The essential oil of Origanum marjorana. Marjoram oil is reported to have sedative effects and to be useful in calming asthma and other respiratory symptoms. 